\title{
Upaya Mitigasi Banjir di Sub DAS Samin Melalui Pengembangan Masyarakat Tangguh Bencana
}

\section{Flood Mitigation Efforts in Samin Sub-Watershed through the Disaster Resilient Community Development}

\author{
WIWIN BUDIARTI ${ }^{1 *}$, EVI GRAVITIANI ${ }^{1}$ DAN MUJIYO ${ }^{2}$ \\ ${ }^{1}$ Program Studi IImu Lingkungan, Program Pasca Sarjana, UNS \\ ${ }^{2}$ Dosen Program Studi IImu Tanah, Fakultas Pertanian, UNS \\ JI. Ir. Sutami No. 36A, Kentingan, Surakarta, Jawa Tengah \\ windy_nindinindya@yahoo.com
}

\begin{abstract}
Floods due to overflowing of Samin river is a problem that often occurs in Sukoharjo District, and impacts enormous socio-economic losses. The new paradigm focuses much on disaster risk reduction (mitigation). The communities are the first to deal with such disaster risk and as a result, it requires their acitve participation so that disaster mitigation capacity would be more effective. The study aims to identify potential flood vulnerability and analysis the flood disaster mitigation efforts through the disaster resilient community development as a form of community participation in Samin sub-watershed. The method of using geographic information system (GIS) in order to map-overlay approach and scoring on several parameters (slope, soil type, drainage density, precipitation and land use) and survey interviews were conducted to determine the mitigation measures are applied. The results showed that the level of flood vulnerability in Samin sub-watershed mostly include vulnerable level - that is very prone area of 53,826,73 hectares (84.77\%). Among the most vulnerable areas include those located in the lower and middle areas such as Mojolaban, Polokarto, Bendosari, Sukoharjo, Karanganyar, Jumapolo, Jaten, Karanganyar, and Kebakkramat District. The village of Tegalmade located in Mojolaban district is classified among the areas with high level of flood vulnerability. The result of this flood disaster vulnerability maps can be integrated as a recommendation in making spatial planning based on disaster mitigation. Flood disaster mitigation efforts for disaster risk reduction imply the application of a disaster resilient community development in the Tegalmade village. A strong community development against disasters would thwart and minimize any potential vulnerability and impacts from flood.
\end{abstract}

Keyword : flood vulnerability, mitigation, gis, disaster resilient communities

\begin{abstract}
ABSTRAK
Bencana banjir akibat luapan Sungai Samin menjadi salah satu permasalahan utama di Kabupaten Sukoharjo. Perlu pengendalian bencana yang lebih menekankan pada pengurangan resiko (mitigasi). Masyarakat sebagai pihak pertama yang berhadapan dengan resiko bencana sehingga mitigasi lebih efektif dengan partisipasi aktif masyarakat. Penelitian bertujuan untuk memetakan potensi tingkat kerawanan banjir dan menganalisis upaya mitigasi bencana banjir melalui program pengembangan masyarakat tangguh bencana sebagai bentuk partisipasi masyarakat di Sub DAS Samin. Metode menggunakan teknologi sistem informasi geografis (SIG) dengan pendekatan map-overlay dan scoring beberapa peta parameter banjir (kemiringan lereng, jenis tanah, kerapatan drainase, curah hujan dan penggunaan lahan) dan survey wawancara untuk mengetahui upaya mitigasi yang diterapkan. Hasil menunjukkan bahwa tingkat kerawanan banjir wilayah Sub DAS Samin sebagian besar termasuk tingkat rawan - sangat rawan yaitu seluas $53,826,73 \mathrm{Ha}(84,77 \%)$. Daerah yang termasuk kategori rawan sangat rawan berada di wilayah hilir dan tengah meliputi Kecamatan Mojolaban, Polokarto, Bendosari, Sukoharjo, Karanganyar, Jumapolo, Jaten, Karanganyar, dan Kebakkramat. Berdasarkan hasil analisis spasial dan wawancara bahwa Desa Tegalmade yang terletak di Kecamatan Mojolaban merupakan daerah dengan tingkat kerawanan bencana banjir tinggi. Hasil peta kerawanan bencana banjir dapat diintegrasikan sebagai sebuah rekomendasi dalam perencanaan tata ruang berbasis mitigasi bencana. Upaya mitigasi bencana banjir yang diterapkan yaitu dengan pengembangan masyarakat tangguh bencana di Desa Tegalmade. Pengembangan masyarakat tangguh bencana dilakukan melalui penyiapan infrastruktur berupa perbaikan tanggul secara permanen, perbaikan lingkungan berupa penanaman tanaman konservasi "Bambu" di sempadan sungai, penyiapan kelembagaan dan kesiapsiagaan baik pemerintah terkait maupun masyarakat rawan bencana, sehingga potensi kerawanan banjir dan dampak yang ditimbulkan bisa diminimalisir.
\end{abstract}


Kata kunci : kerawanan banjir, mitigasi, sig, masyarakat tangguh bencana

\section{PENDAhULUan}

Bencana merupakan rangkaian peristiwa yang mengancam dan mengganggu kehidupan dan penghidupan masyarakat disebabkan oleh faktor alam dan/atau non alam maupun faktor manusia sehingga mengakibatkan timbulnya korban jiwa manusia, kerusakan lingkungan, kerugian harta benda dan dampak psikologis ${ }^{(1)}$. Bencana banjir merupakan salah satu jenis bencana yang berdasarkan Data Informasi Bencana Indonesia (DIBI) paling banyak terjadi dan cenderung meningkat beberapa tahun terakhir. Banjir merupakan peristiwa debit aliran air sungai yang secara relatif lebih besar dari biasanya/normal akibat hujan yang turun di hulu atau di suatu tempat tertentu secara terus menerus, sehingga tidak dapat ditampung oleh alur sungai yang ada, maka air meluap keluar dan menggenangi daerah sekitarnya ${ }^{(2)}$.

Berdasarkan data kejadian bencana beberapa tahun terakhir, menunjukkan bahwa banjir sering mengancam di wilayah Sub Daerah Aliran Sungai (DAS) Samin. Sub DAS Samin merupakan bagian dari DAS Bengawan Solo hulu yang merupakan salah satu dari 108 DAS kritis di Indonesia (SK Menteri Kehutanan No. 328/Menhut-II/2009). Kondisi Sub DAS Samin saat ini kritis ditunjukkan dengan besarnya erosi dan sedimentasi sehingga berpotensi terjadi banjir $^{(3)}$. Tercatat telah terjadi bencana banjir besar dan dampak terbesar akibat luapan Sungai Samin, pada tahun 2007, 2013, 2015 dan 2016.

Permasalahan kompleks di Sub DAS Samin yang berpangkal pada tekanan penduduk yang sangat berat berdampak menurunnya fungsi dan daya dukung DAS. Terganggunya fungsi hidrologis ekosistem DAS ini menyebabkan sangat berkurangnya tingkat penangkapan curah hujan, resapan dan penyimpanan air atau bisa dikatakan sistem penyalurannya menjadi sangat boros sehingga mengakibatkan bencana banjir di musim penghujan ${ }^{(4)}$ seperti yang terjadi di wilayah Sub DAS Samin.

Bencana banjir disebabkan oleh faktor alam dan kegiatan manusia yang terkait dengan pemanfaatan sumberdaya alam yang menyebabkan degradasi dan kerusakan $D A S^{(5)}$. Faktor alam terutama disebabkan intensitas curah hujan yang sangat tinggi dan kondisi karakteristik DAS, sedangkan faktor manusia disebabkan adanya perubahan penggunaan lahan, sarana prasarana drainase belum baik serta sosial kelembagaan pemerintah dan masyarakat belum mantap.
Banjir menimbulkan dampak kerusakan dan kerugian bisa berupa korban manusia dan harta benda sehingga mengganggu bahkan melumpuhkan kegiatan sosial-ekonomi penduduk $^{(6)}$. Bencana banjir juga telah menimbulkan banyak kerusakan lingkungan, baik lingkungan alami (erosi tebing, sedimentasi, pendangkalan sungai), maupun lingkungan buatan (kerusakan/kerugian sektor pertanian, pemukiman, sarana umum $)^{(7)}$. Sehingga bencana banjir perlu mendapat perhatian khusus, karena bencana tersebut menelan korban jiwa dan kerugian terbesar $(40 \%)$ dari seluruh kerugian bencana alam ${ }^{(8)}$.

Upaya pengendalian bencana banjir yang telah dilakukan pemerintah masih didominasi dengan pendekatan struktur (bangunan teknis), sedangkan pendekatan non struktur masih jarang dilakukan. Menurut Badan Nasional Penanggulangan Bencana (BNPB), paradigma baru pengendalian bencana lebih menekankan pada pengurangan resiko bencana (mitigasi). Mitigasi merupakan serangkaian upaya untuk mengurangi resiko bencana, baik melalui pembangunan fisik maupun penyadaran dan peningkatan kemampuan menghadapi ancaman bencana $^{(1)}$.

Masyarakat merupakan pihak pertama yang berhadapan dengan resiko bencana sehingga kapasitas mitigasi bencana lebih efektif dengan partisipasi masyarakat. Salah satu hal yang harus diperhatikan dalam upaya mitigasi, yaitu tersedianya informasi dan peta daerah rawan bencana serta sosialisasi untuk meningkatkan kesadaran masyarakat dalam menghadapi bencana ${ }^{(9)}$.

Penelitian ini bertujuan untuk memetakan potensi tingkat kerawanan bencana banjir dan menganalisis upaya mitigasi bencana banjir di Sub DAS Samin melalui pengembangan masyarakat tangguh bencana.

\section{BAHAN DAN METODE}

Penelitian dilakukan di wilayah Sub DAS Samin, dan secara khusus mengambil studi kasus di Desa Tegalmade, yang secara administratif terletak di Kecamatan Mojolaban, Kabupaten Sukoharjo, Provinsi Jawa Tengah dan merupakan bagian hilir Sub DAS Samin.

Pengumpulan data biofisik berupa Peta Administrasi Provinsi Jawa Tengah, Peta Batas Sub DAS Samin, Peta Tanah Tinjau, Peta Kontur, Peta Jaringan Sungai, Peta Curah Hujan dan Peta Penggunaan Lahan (format digital) 
diperoleh dari Balai Penelitian dan Pengembangan Teknologi Pengelolaan Daerah Aliran Sungai (BP2TPDAS) dan Program Studi IImu Tanah Universitas Sebelas Maret. Untuk data sosial ekonomi diperoleh dari Badan Penanggulangan Bencana Daerah (BPBD) Kabupaten Sukoharjo, Dinas Pertanian Kabupaten Sukoharjo dan wawancara responden dan key person terkait.

Metode yang digunakan untuk mengidentifikasi potensi kerawanan banjir dengan memanfaatkan teknologi Sistem Informasi Geografis (SIG), karena teknologi SIG bisa membantu upaya mitigasi bencana alam melalui identifikasi lokasi bencana ${ }^{(6,10)}$, software arcview 3.3 dengan pendekatan map-overlay (tumpangsusun peta) dan scoring terhadap tema peta parameter. Parameter yang berpengaruh terhadap kerawanan banjir meliputi kemiringan lereng, jenis tanah, curah hujan, kerapatan aliran, dan penggunaan lahan ${ }^{(11,12,13)}$.

Parameter kerawanan banjir tersebut diklasifikasikan dan diberikan bobot berdasarkan tingkat pengaruhnya dalam terjadinya ancaman bencana banjir serta mengacu beberapa referensi. Selanjutnya memberikan harkat dan skor terhadap setiap peta parameter sesuai bobot parameter kerawanan banjir (Tabel 1).

Tabel 1. Pemberian harkat dan skor parameter kerawanan banjir

\begin{tabular}{lccc}
\hline \multicolumn{1}{c}{ Parameter } & Harkat & Bobot & Skor \\
\hline 1. Kemiringan Lereng (\%) & & \\
\hline $0-8$ & 5 & 5 & 25 \\
\hline $8-15$ & 4 & 5 & 20 \\
\hline $15-25$ & 3 & 5 & 15 \\
\hline $25-40$ & 2 & 5 & 10 \\
\hline$\geq 40$ & 1 & 5 & 5 \\
\hline
\end{tabular}

(Sumber: Chow, 1968 dalam Permenhut No.32/2009)

2. Jenis Tanah

\begin{tabular}{|c|c|c|c|}
\hline Aluvial & 5 & 3 & 15 \\
\hline Latosol, Litosol & 4 & 3 & 12 \\
\hline Regosol, Grumusol & 3 & 3 & 9 \\
\hline $\begin{array}{l}\text { Andosol coklat, } \\
\text { Mediteran }\end{array}$ & 2 & 3 & 6 \\
\hline Andosol hitam & 1 & 3 & 3 \\
\hline
\end{tabular}

3. Kerapatan Drainase

\begin{tabular}{|c|c|c|c|}
\hline$<0,62$ & 5 & 3 & 15 \\
\hline $0,62-1,44$ & 4 & 3 & 12 \\
\hline $1,45-2,27$ & 3 & 3 & 9 \\
\hline $2,28-3,10$ & 2 & 3 & 6 \\
\hline$>3,10$ & 1 & 3 & 3 \\
\hline $\begin{array}{l}\text { (Sumber: Anna, et.al, } \\
\text { Matondang et al., 2013) }\end{array}$ & 2015 & et & 2014 \\
\hline
\end{tabular}

\begin{tabular}{llll}
\hline 4. Curah Hujan & & & \\
\hline$>5500$ & 5 & 2 & 10 \\
\hline $4500-5500$ & 4 & 2 & 8 \\
\hline $3500-4500$ & 3 & 2 & 6 \\
\hline $2500-3500$ & 2 & 2 & 4 \\
\hline$<2500$ & 1 & 2 & 2 \\
\hline
\end{tabular}

(Sumber: Wischmeier, 1958; Chow, 1968; Wiersum \& Ambar, 1980 dalam Permenhut No.32/2009)

\begin{tabular}{llll}
\hline 5. Penggunaan Lahan & & & \\
\hline $\begin{array}{l}\text { Pemukiman, } \\
\text { gedung, sawah }\end{array}$ & 5 & 2 & 10 \\
\hline $\begin{array}{l}\text { Holtikultura, } \\
\text { tegalan, ladang }\end{array}$ & 4 & 2 & 8 \\
\hline $\begin{array}{l}\text { Semak belukar, } \\
\text { padang rumput }\end{array}$ & 3 & 2 & 5 \\
\hline Perkebunan & 2 & 2 & 4 \\
\hline Hutan & 1 & 2 & 2 \\
\hline
\end{tabular}

(Sumber: Chow, 1968; Suwardjo, 1975;Wiersum \& Ambar, 1980; S. Ambar, 1986 dalam Permenhut No.32/2009)

Tahap terakhir melakukan map-overlay lima tema peta parameter kerawanan banjir dan menjumlahkan skor total terhadap peta hasil overlay (Tabel 2) sehingga diperoleh Peta Kerawanan Banjir di Sub DAS Samin.

Tabel 2. Klasifikasi tingkat kerawanan banjir di Sub DAS Samin

\begin{tabular}{ll}
\hline Kategori & Skor Total \\
\hline Tidak Rawan & $25-33$ \\
\hline Agak Rawan & $34-41$ \\
\hline Cukup Rawan & $42-49$ \\
\hline Rawan & $50-57$ \\
\hline Sangat Rawan & $58-66$ \\
\hline \multicolumn{2}{l}{ Sumber: Aji,et.al, 2014 \& Matondang,et.al,2013 }
\end{tabular}

Sedangkan untuk menganalisis upaya mitigasi melalui pengembangan masyarakat tangguh bencana menggunakan metode survey, wawancara terhadap beberapa key person dan analisis data dilakukan secara deskriptif.

\section{HASIL DAN PEMBAHASAN}

\subsection{Tingkat Kerawanan Banjir Sub DAS Samin}

Kerawanan banjir merupakan keadaan yang menggambarkan mudah tidaknya suatu daerah terkena banjir berdasarkan faktor-faktor yang berpengaruh terhadap kejadian banjir.

Hasil analisis parameter kemiringan lereng pada Gambar 1, menunjukkan bahwa kondisi kemiringan lereng di wilayah Sub DAS Samin sebagian besar relatif datar dengan kelerengan $0-8 \%$ dan hampir tersebar merata yaitu seluas $50.991,9 \mathrm{Ha}(80,3$ \%). Wilayah kajian Desa 
Tegalmade termasuk kelas kelerengan datar. Kondisi geomorfologi seperti dataran alluvial, lembah alluvial, kelokan sungai dan rawa-rawa merupakan daerah yang rawan banjir karena merupakan daerah rendah atau cekungan dengan lereng $<2 \%{ }^{(2,14)}$. Berdasarkan parameter kemiringan lereng dapat diklasifikasikan bahwa wilayah Sub DAS Samin memiliki tingkat kerawanan banjir yang tinggi karena sebagian besar wilayahnya datar. Kemiringan lereng semakin datar, maka aliran limpasan permukaan menjadi lambat dan kemungkinan terjadi genangan/banjir besar.

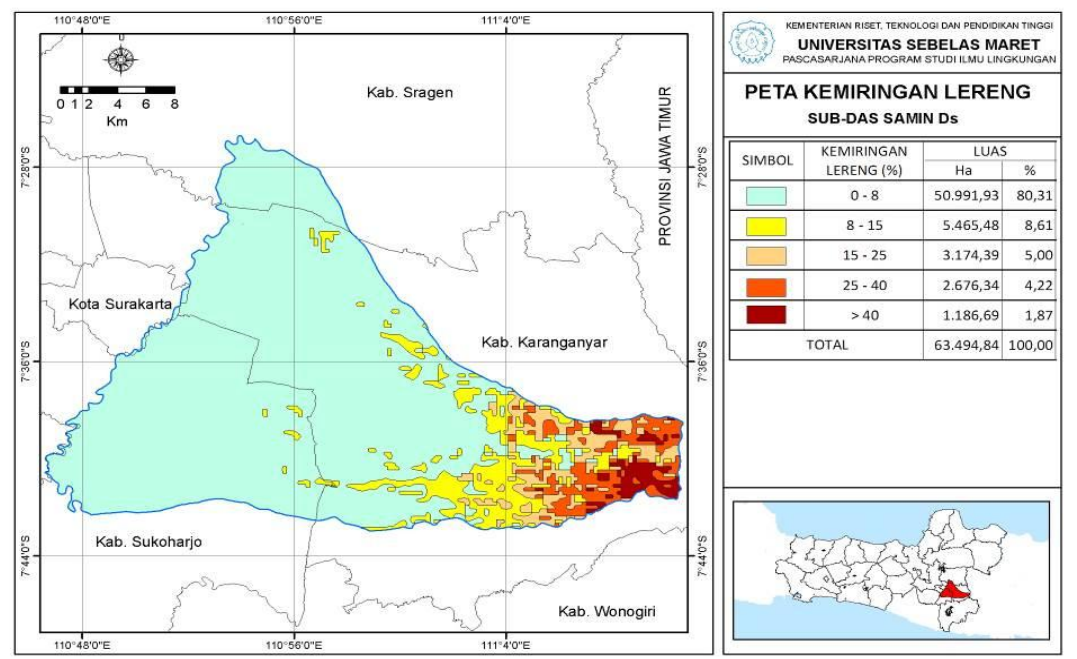

Gambar 1. Peta kemiringan lereng sub DAS Samin

(Sumber: hasil pengolahan dan analisis data sekunder, 2016)

Jenis tanah merupakan cerminan kondisi tekstur tanah dan mudah atau tidaknya curah hujan yang meresap ke dalam tanah (infiltrasi) ${ }^{(9)}$. Hasil analisis jenis tanah wilayah Sub DAS Samin bisa dilihat pada Gambar 2, terlihat bahwa jenis tanah alluvial coklat keabuan merupakan jenis tanah paling dominan yang sebagian besar terletak di bagian hilir Sub DAS Samin yaitu seluas $17.509,5 \mathrm{Ha}(27,70 \%)$, dimana Desa Tegalmade termasuk wilayah tersebut. Tanah dengan tekstur halus memiliki tingkat infiltrasi rendah sehingga menimbulkan aliran permukaan meningkat. Berdasarkan parameter jenis tanah, mengindikasikan bahwa sebagian besar wilayah Sub DAS Samin memiliki tingkat kerawanan banjir yang tinggi.

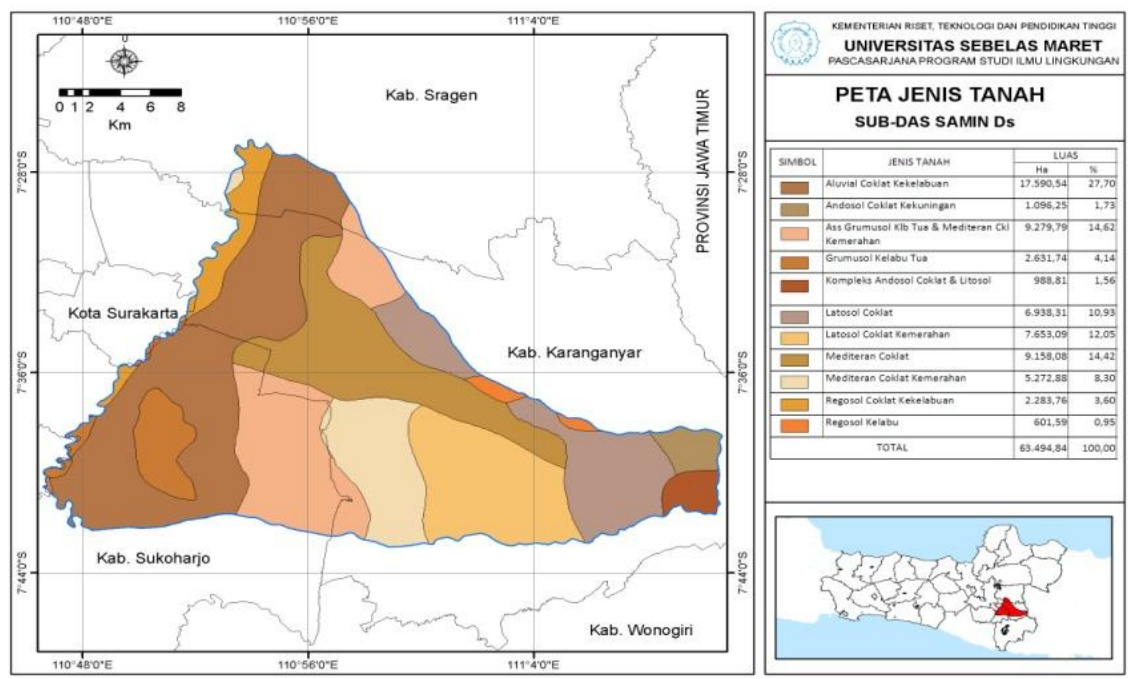

Gambar 2. Peta jenis tanah sub DAS Samin

(Sumber: hasil pengolahan dan analisis data sekunder, 2016) 
Hasil analisis kelas kerapatan drainase (Gambar 3), menunjukkan bahwa sebagian besar wilayah di Sub DAS Samin memiliki kerapatan drainase rendah sampai sedang, dengan nilai kerapatan aliran 0,62-1,44 km/km² $(19,47 \%)$ dan $1,45-2,27 \mathrm{~km} / \mathrm{km}^{2}(75,74 \%)$ dan sebagian besar terletak di bagian tengah dan hilir. Sedangkan kerapatan drainase tinggi hanya sebagian kecil terletak di bagian hulu Sub DAS Samin. Semakin rendah nilai kerapatan drainase maka sistem pengaliran (drainase) semakin buruk sehingga kemungkinan terjadinya banjir semakin besar. Diungkapkan bahwa semakin besar nilai kerapatan aliran maka semakin baik sistem pengaliran (drainase) $^{(4)}$. Berdasarkan parameter kerapatan drainase bisa disimpulkan bahwa wilayah Sub DAS Samin memiliki tingkat kerawanan banjir sedang sampai tinggi.

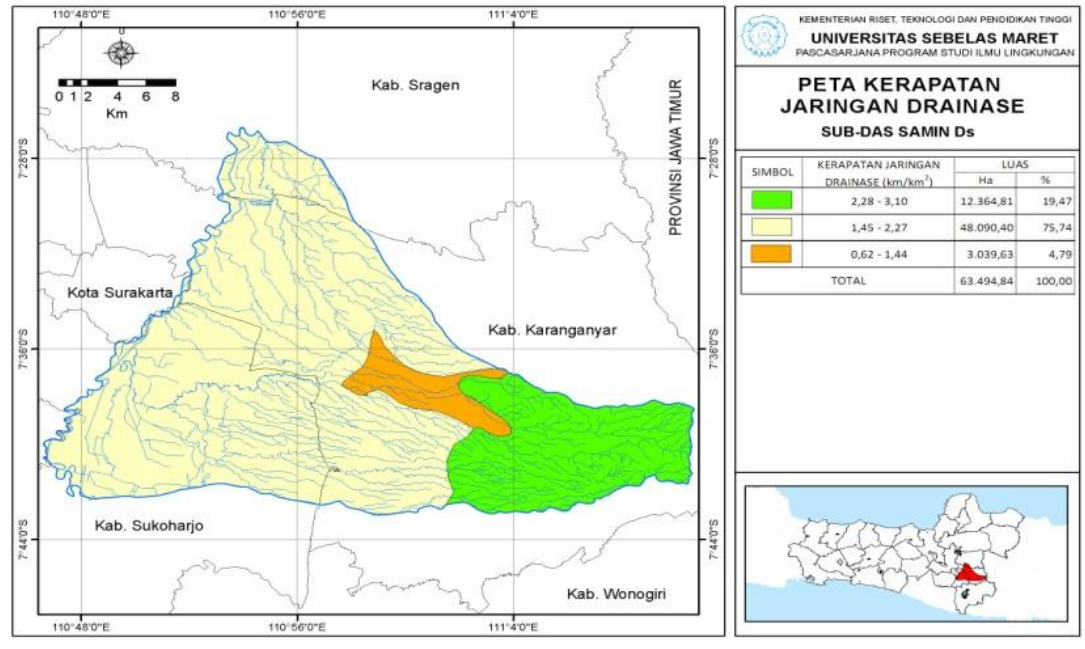

Gambar 3. Peta kerapatan drainase sub DAS Samin

(Sumber: hasil pengolahan dan analisis data sekunder, 2016)

Penggunaan lahan merupakan salah satu parameter penting dalam penentuan tingkat kerawanan banjir. Tipe penggunaan lahan, khususnya tipe vegetasi penutup tanah, sangat berpengaruh terhadap infiltrasi melalui kemampuan perakaran dan pori-pori memperbesar permeabilitas tanah, vegetasi menahan run-off dan vegetasi mengurangi jumlah air perkolasi melalui transpirasi ${ }^{(13)}$. Kondisi penutupan lahan hutan merupakan faktor yang sangat berpengaruh terhadap terjadinya banjir ${ }^{(2)}$.

Hasil analisis Peta Penggunaan Lahan (Gambar 4), bahwa sebagian besar wilayah di Sub DAS Samin memiliki kelas penggunaan lahan pemukiman, gedung, sawah dan rawa sebesar 49.245,9 $\mathrm{Ha}(77,4 \%)$, sedangkan penggunaan lahan hutan dan kebun hanya sedikit sekitar 1,1\% dan 6,9\% berada di bagian hulu Sub DAS Samin.

Penggunaan lahan berupa lahan terbuka, pemukiman, sawah, sungai, waduk dan rawa memiliki nilai koefisien limpasan permukaan yang besar, karena air hujan yang jatuh langsung dialirkan menjadi limpasan permukaan sehingga resiko terjadinya banjir besar, sebaliknya penggunaan lahan berupa hutan rapat akan memperkecil limpasan permukaan dan resiko terjadi banjir kecil. Berdasarkan parameter penggunaan lahan dapat disimpulkan bahwa sebagian besar wilayah di Sub DAS Samin memiliki tingkat kerawanan banjir yang tinggi. 


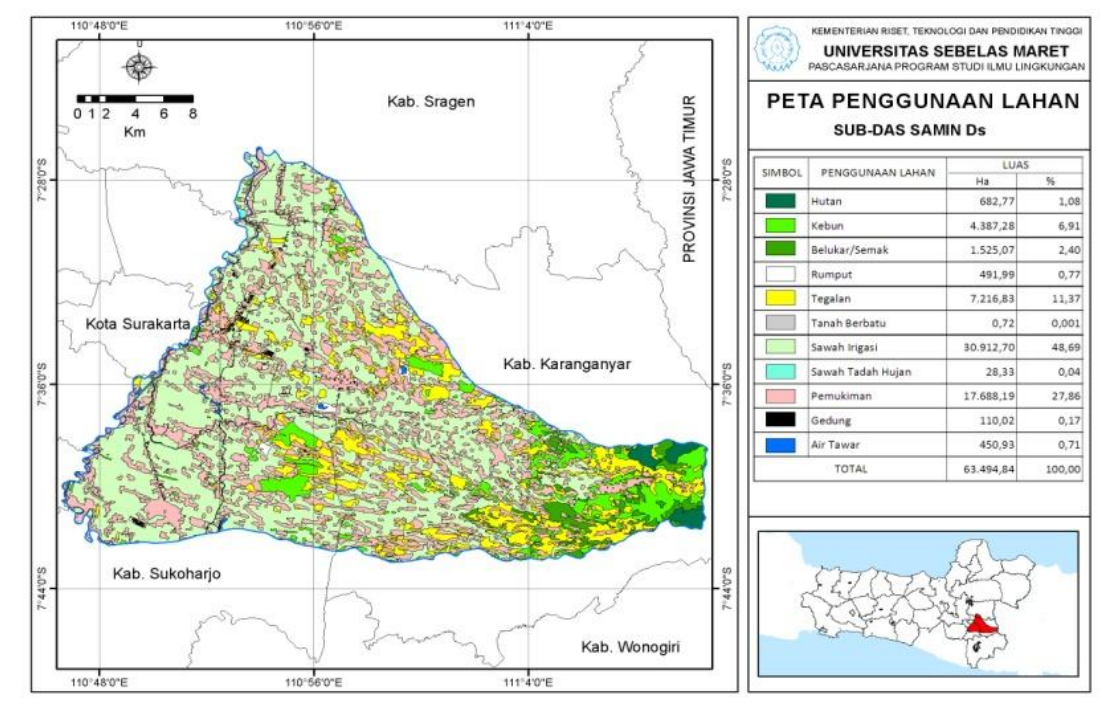

Gambar 4. Peta Penggunaan Lahan Sub DAS Samin

(Sumber: hasil pengolahan dan analisis data sekunder, 2016)

Curah hujan merupakan salah satu faktor penyebab terjadi banjir, banjir besar terjadi apabila air hujan cukup tinggi dan jatuh tersebar merata di seluruh daerah tangkapan air, kemudian berubah menjadi limpasan permukaan yang terkumpul secara cepat pada suatu outlet ${ }^{(2)}$. ${ }^{(12)}$ Mengungkapkan besar intensitas curah hujan dan kemiringan lereng suatu daerah menentukan rawan atau tidaknya daerah tersebut terancam banjir. Dalam proses resapan, sebagian air hujan akan meresap ke dalam tanah (infiltrasi) dan sebagian menjadi air Iarian (run off). Gambar 5, menunjukkan bahwa wilayah di Sub DAS Samin memiliki curah hujan rendah sampai sedang.

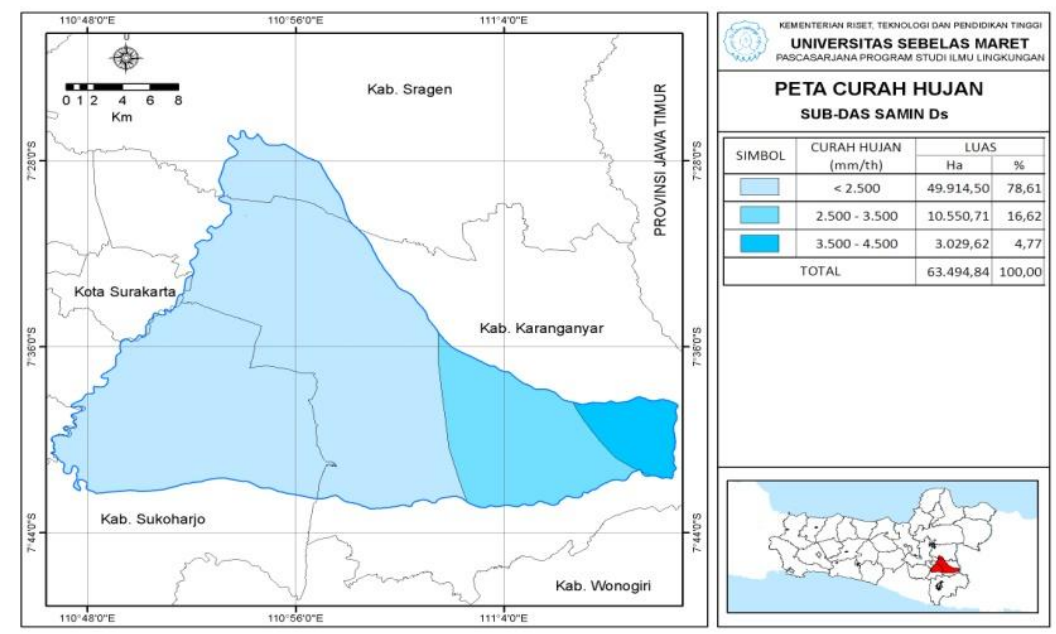

Gambar 5. Peta curah hujan sub DAS Samin

(Sumber: hasil pengolahan dan analisis data sekunder, 2016)

Penyusunan Peta Kerawanan Banjir Sub DAS Samin dilakukan dengan menggunakan teknologi SIG seperti penelitian yang dilakukan dalam menganalisis daerah rawan tanah longsor $^{(10)}$ dan analisis lahan kritis di DAS Agam Kuantan ${ }^{(15)}$, yaitu dengan menumpangsusun hasil analisis lima tema peta yaitu peta kemiringan lereng, peta jenis tanah, peta kerapatan drainase, peta curah hujan dan peta penggunaan lahan. Hasil proses overlay tersebut dijumlahkan skor total pada tiap kelas parameter dan diklasifikasikan, dimana semakin tinggi skor total yang dihasilkan maka memiliki tingkat kerawanan banjir semakin tinggi.

Peta kerawanan banjir Sub DAS Samin bisa dilihat pada Gambar 6, menunjukkan bahwa wilayah Sub DAS Samin memiliki tingkat kerawanan banjir bervariasi dengan klasifikasi tingkat kerawanan banjir terdiri dari daerah tidak rawan sampai sangat rawan. Tingkat kerawanan 
banjir tidak rawan seluas $1.656,5$ ha $(2,61 \%)$, agak rawan seluas $3.194,8 \mathrm{Ha}(5,03 \%)$, cukup rawan seluas $4.816,8 \mathrm{Ha}(7,59 \%)$, rawan seluas $32.298,7 \mathrm{Ha}(50,87 \%)$ dan sangat rawan seluas
$21.528,0 \mathrm{Ha}(33,91 \%)$. Tingkat kerawanan banjir di Sub DAS Samin didominasi kategori "rawan sampai sangat rawan" dengan total seluas $53.826,73 \mathrm{Ha}$ atau $84,77 \%$.

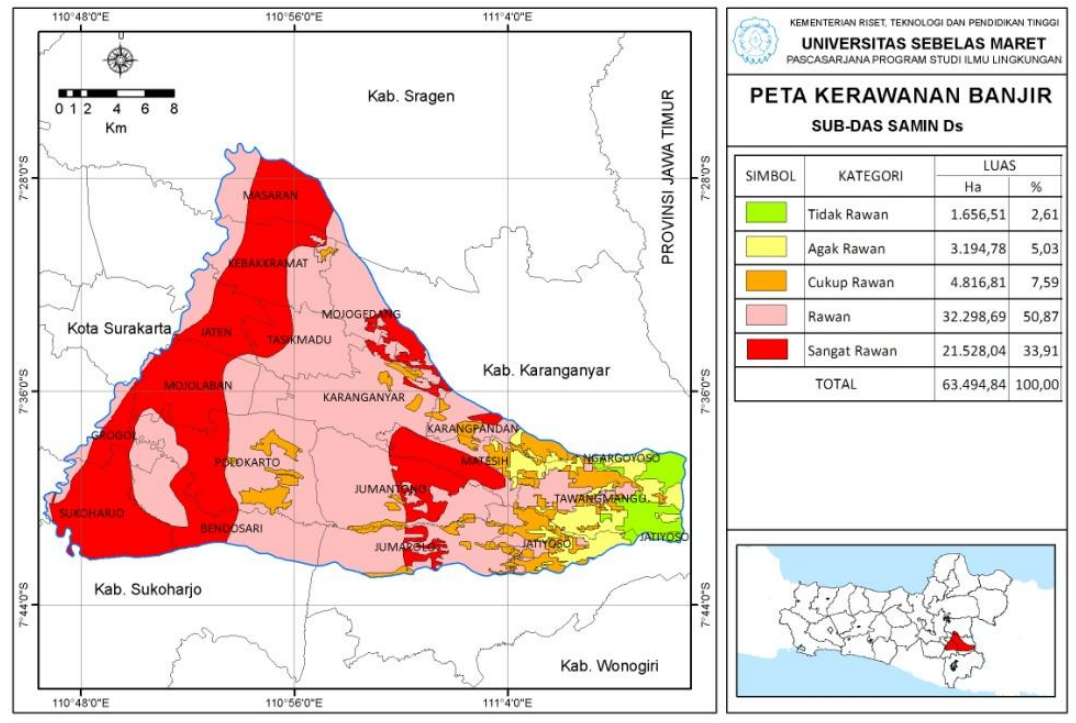

Gambar 6. Peta kerawanan banjir di sub DAS Samin (Sumber: hasil pengolahan dan analisis data sekunder, 2016)

Tingkat kerawanan banjir kategori rawan sampai sangat rawan terletak di Kecamatan Mojolaban, Polokarto, Sukoharjo, Bendosari, Grogol, Jaten, Karanganyar, Kebakkramat dan Jumapolo. Hal ini dipengaruhi beberapa faktor seperti topografi wilayah datar dengan kemiringan $0-8 \%$, kerapatan drainase rendah sampai sedang, dan tipe penggunaan lahan dominan adalah pemukiman, sawah, gedung, dan tegalan. Sedangkan tingkat kerawanan banjir kategori tidak rawan sampai agak rawan terletak di Kecamatan Tawangmangu dan Jatiyoso, dengan topografi wilayah curam sampai sangat curam, kerapatan drainase tinggi dan tipe penggunaan lahan hutan, perkebunan, semak belukar.

Hasil analisis faktor yang mempengaruhi tingkat kerawanan banjir terdiri dari kondisi kemiringan lereng, jenis tanah, kerapatan drainase, tipe penggunaan lahan dan curah hujan, dimana kelima faktor tersebut dianalisis secara terpadu. Tetapi faktor paling dominan mempengaruhi kerawanan banjir di Sub DAS Samin adalah kemiringan lereng, jenis tanah, penggunaan lahan dan kerapatan drainase. Kondisi kemiringan lereng di daerah penelitian didominasi kelas lereng $0-8 \%$ (datar) sebesar $51.014,6 \mathrm{Ha}(80,2 \%)$, sedangkan tipe penggunaan lahan didominasi tipe pemukiman, gedung, sawah dan badan air/rawa yaitu sebesar 49.245,9 $\mathrm{Ha}$ (77,4\%), jenis tanah dominan merupakan tanah alluvial.

\subsection{Upaya Mitigasi Melalui Pengembangan Masyarakat Tangguh Bencana}

Penyediaan informasi dan peta tingkat kerawanan banjir di Sub DAS Samin melalui teknologi SIG ini merupakan salah satu upaya mitigasi bencana banjir non struktural ${ }^{(6)}$, sehingga bisa digunakan para pengambil kebijakan dalam merancang strategi pengendalian banjir. Peta kerawanan banjir Sub DAS Samin yang ditunjukkan pada Gambar 6 menjadi bagian dari sistem peringatan dini (early warning sistem) sehingga resiko dan bahaya bencana banjir bisa diperkirakan sehingga pada akhirnya bisa meminimalisir dampak ${ }^{(10)}$.

Pengendalian bencana banjir akan lebih efektif jika melibatkan masyarakat karena masyarakat adalah pihak yang pertama kali berhadapan langsung dengan resiko bencana, sekaligus proses pembelajaran kepada masyarakat tentang banjir dan pentingnya konservasi lahan untuk pengendalian banjir ${ }^{(16)}$. Jika terjadi bencana, masyarakat yang tinggal di kawasan rawan akan menjadi pihak yang paling dirugikan. Sesuai UU Nomor 24 Tahun 2007 tentang Penanggulangan Bencana mengamanatkan untuk melindungi masyarakat dari ancaman bencana. Salah satu strategi untuk mewujudkan hal tersebut adalah melalui pengembangan masyarakat tangguh bencana sebagai upaya pengurangan risiko bencana berbasis komunitas (PRBBK). Suatu daerah sulit dikatakan bebas dari bencana banjir karena kemungkinan terjadi debit yang sama atau 
bahkan melampaui debit akan selalu ada dalam setiap tahunnya, sehingga upaya yang perlu dilakukan dalam menanggulangi banjir adalah meminimalkan dampak/resiko yang ditimbulkan akibat bencana banjir atau yang disebut dengan mitigasi ${ }^{(17)}$.

Berdasarkan hasil analisis data spasial beberapa kecamatan di Kabupaten Sukoharjo memiliki tingkat kerawanan banjir tinggi termasuk Desa Tegalmade. Desa Tegalmade terletak di bagian hilir Sub DAS Samin yang secara administrative berada di Kecamatan Mojolaban Kabupaten Sukoharjo yang setiap tahun terdampak bencana banjir akibat luapan Sungai Samin. Hasil analisis deskriptif dari wawancara responden dan key person, salah satu bentuk upaya mitigasi bencana banjir yang dilakukan untuk pengurangan resiko bencana di wilayah Sub DAS Samin adalah dengan Pengembangan Desa Tangguh Bencana (Destana) di Desa Tegalmade sejak tahun 2015. Upaya ini dilakukan agar masyarakat yang berada di daerah rawan bencana dapat mandiri mengantisipasi bencana banjir yang terjadi. Desa Tangguh Bencana adalah desa yang memiliki kemampuan mandiri untuk beradaptasi dan menghadapi potensi ancaman bencana, serta memulihkan diri dengan segera dari dampak-dampak bencana yang merugikan (Perka BNPB Nomor 1 Tahun 2012).

Beberapa upaya yang dilakukan dalam pengembangan masyarakat tangguh bencana di Desa Tegalmade, antara lain penyiapan infrastruktur, perbaikan lingkungan, penyiapan kelembagaan dan kesiapsiagaan baik pemerintah terkait maupun masyarakat rawan bencana. Dengan adanya pengembangan masyarakat tangguh bencana ini maka potensi kerawanan banjir dan dampak yang ditimbulkan bisa diminimalisir.

Penyiapan infrastruktur untuk pengembangan desa siaga bencana di Desa Tegalmade meliputi perbaikan bangunan tanggul Sungai Samin di Dusun Kesongo, Desa Tegalmade, Kecamatan Mojolaban secara permanen sepanjang 50 meter dengan tinggi 10 meter. Perbaikan dilakukan secara bertahap oleh Balai Besar Wilayah Sungai Bengawan Solo (BBWSBS). Sebelumnya telah dipasang beronjong kawat berisi batu pada tanggul tersebut, namun kondisi sebagian jebol karena diterjang aliran sungai yang deras akibat intensitas hujan yang lebat sehingga berdampak banjir di wilayah sekitarnya. Selain itu dilakukan penyiapan jalur dan tempat evakuasi sementara. Dikarenakan belum dibangun bangunan evakuasi permanen sehingga posko evakuasi sementara berada di Pendopo Balai Desa Tegalmade dan Rumah Kepala Dusun Kesongo Desa Tegalmade (Bp. Sumanto) karena posisi lebih tinggi dan luas sehingga cukup untuk menampung warga yang terdampak bencana banjir.

Untuk mendukung keberhasilan upaya mitigasi bencana yang dilakukan, sebaiknya pembangunan infrastruktur yang bersifat sipil teknis seperti pembangunan tanggul perlu dikombinasi teknik konservasi lahan secara vegetatif guna perlindungan DAS. Teknik yang dimaksud diantaranya adalah dengan penanaman "Bambu" sebagai tanaman konservasi di sempadan sungai. Tanaman bambu berfungsi sebagai tanaman konservasi karena mampu memperbaiki sumber tangkapan air sehingga mampu meningkatkan water storage, sistem perakaran sangat rapat, kuat dan menyebar ke segala arah serta memiliki struktur yang unik terkait secara vertikal dan horizontal sehingga tidak mudah putus dan berdiri kokoh untuk menahan erosi dan longsor akibat gerusan air sungai. Selain itu lahan di bawah tegakan bambu sangat stabil dan mudah meresapkan air sehingga sangat cocok untuk menjaga fungsi hidrologis DAS ${ }^{[18]}$.

Pelibatan masyarakat secara aktif dalam pengembangan Desa Tangguh Bencana dalam setiap proses pengelolaan resiko bencana, meliputi tahapan dalam mengkaji, menganalisis, menangani, memantau dan mengevaluasi risiko bencana untuk mengurangi kerawanan dan meningkatkan kapasitas guna pengurangan resiko bencana banjir yang terjadi, dengan memanfaatkan sumber daya lokal.

Masyarakat Desa Tegalmade memiliki tingkat partisipasi cukup tinggi dalam upaya mitigasi dampak bencana banjir, terlihat dari keterlibatan aktif masyarakat dalam pengembangan Destana di Desa Tegalmade yang sekaligus menjadi pilot project dari BPBD Kabupaten Sukoharjo. Hal ini disebabkan wilayah terdampak bencana banjir di Desa Tegalmade sangat besar khususnya di sektor pertanian. Berdasarkan hasil survey, masyarakat sudah peka terhadap gejala banjir, masyarakat secara mandiri segera mengevakuasi diri tanpa menunggu sukarelawan bencana tiba di lokasi.

$$
\text { Penyiapan kelembagaan terkait }
$$
pengembangan desa tangguh bencana ini, secara umum tingkat kapasitas pemerintah Kabupaten Sukoharjo dalam menghadapi bencana banjir tergolong sedang sampai tinggi, hal ini mencerminkan bahwa dasar kelembagaan sudah memiliki kemampuan yang baik dalam menghadapi kondisi darurat bencana, pengurangan resiko sudah ada, pembangunan kesiapsiagaan sudah ada tetapi prosedur belum tersusun baik, tetapi pendidikan bencana belum ada. 
Sedangkan tingkat kapasitas masyarakat tergolong sedang, dilihat dari parameter pengetahuan kesiapsiagaan bencana, pengelolaan tanggap darurat, pengaruh kerentanan masyarakat (sosial ekonomi), ketidaktergantungan masyarakat terhadap dukungan pemerintah dan tingkat partisipasi masyarakat. Untuk mengevaluasi progress pelaksanaan pengembangan masyarakat tangguh bencana di Desa Tegalmade, telah diadakan simulasi bencana diikuti oleh aparat dan masyarakat dan hasil mengindikasikan bahwa masyarakat Tegalmade sudah tanggap bencana banjir.

Demi keberlanjutan pengembangan masyarakat tangguh bencana sebagai upaya mitigasi banjir di Sub DAS Samin maka perlu pendampingan partisipasi masyarakat, fasilitasi, bimbingan teknis kepada masyarakat, relawan dan aparat terkait pendidikan kebencanaan banjir, tanggap darurat dan kesiapsiagan bencana serta dilakukan sosialisasi early warning system dan pendidikan konservasi lahan. Selain itu perlu keterlibatan stakeholder ke tengah masyarakat terutama yang beroperasi di daerah rawan bencana sebagai bukti tanggung jawab korporasi dan yang sangat penting peran pemerintah terkait sehingga penanggulangan bencana banjir lebih efektif. Lebih dari itu upaya penanggulangan banjir harus dilakukan secara komprehensif, tidak hanya di bagian hilir saja tetapi konservasi di bagian hulu dari Sub DAS Samin sehingga kerusakan DAS bisa diperbaiki yang pada akhirnya ancaman bencana banjir bisa ditekan.

\section{KESIMPULAN}

Wilayah Sub DAS Samin memiliki tingkat kerawanan banjir bervariasi dengan klasifikasi tingkat kerawanan banjir, terdiri dari daerah tidak rawan sampai sangat rawan. Tingkat kerawanan banjir didominasi kategori "rawan sampai sangat rawan" yaitu total seluas $53.826,73 \mathrm{Ha}$ atau $84,77 \%$ yang terdapat pada bagian hilir dan tengah Sub DAS Samin. Hasil peta kerawanan bencana banjir ini dapat diintegrasikan sebagai sebuah rekomendasi dalam membuat perencanaan tata ruang berbasis mitigasi bencana.

Upaya mitigasi bencana banjir yang diterapkan untuk pengurangan resiko bencana yaitu dengan Pengembangan Masyarakat Tangguh Bencana di Desa Tegalmade yang terletak di Kecamatan Mojolaban, Kabupaten Sukoharjo, dimana berdasarkan peta kerawanan memiliki kategori rawan sampai sangat rawan dan dampak kerusakan pertanian yang tinggi. Kegiatan pengembangan masyarakat tangguh bencana dilakukan melalui penyiapan infrastruktur berupa perbaikan tanggul secara permanen, perbaikan lingkungan berupa penanaman tanaman konservasi "Bambu" di semapadan sungai, penyiapan kelembagaan dan kesiapsiagaan baik pemerintah terkait maupun masyarakat rawan bencana. Dengan melalui pengembanganan masyarakat tangguh bencana maka potensi kerawanan banjir dan dampak resiko bencana yang ditimbulkan bisa diminimalisir.

\section{PERSANTUNAN}

Penulis mengucapkan terima kasih kepada Pusat Pendidikan dan Pelatihan Sumber Daya Manusia Kementerian Lingkungan Hidup dan Kehutanan atas dukungan biaya penelitian, serta kepada Dhidhit Suryono dan adik-adik S1 Agroteknologi Universitas Sebelas Maret (Aziz, Dio, Idam, Adi, Angga dan Azhar) atas semangat dan bantuannya dalam pengambilan data di lapangan.

\section{DAFTAR PUSTAKA}

1. Undang-undang Republik Indonesia nomor 4 Tahun 2007 tentang Penanggulangan Bencana.

2. Paimin, Sukresno, \& Pramono, I.B., (2009), Teknik Mitigasi Banjir dan Tanah Longsor, Tropenbos International Indonesia Programme.

3. Maridi, Agustina, P. \& Sapura, A., (2014), Vegetation Analysis of Samin Watershed, Central Java, as Water and Soil Conservation Efforts, Biodiversitas Journal, 15 (2), 215-223.

4. Asdak, C., (2010), Hidrologi dan Pengelolaan Daerah Aliran Sungai, Cetakan ke 5, Yogyakarta: Gadjah Mada University Press.

5. Nugroho, S.P., (2015), Relevansi Meningkatnya Bencana Hidrometeorologi terkait Kerusakan DAS di Indonesia, Prosiding Seminar Nasional Restorasi DAS: Mencari Keterpaduan di Tengah Isu Perubahan Iklim, Surakarta: BPTKPDAS.

6. Puturuhu, F., (2015), Mitigasi Bencana dan Pengeinderaan Jauh, Cetakan ke 1, Yogyakarta: Graha Ilmu.

7. Suherlan, E., (2001), Zonasi Tingkat Kerentanan Banjir Kabupaten Bandung, Skripsi, Fakultas Matematika dan IImu Pengetahuan Alam, Institut Pertanian Bogor.

8. Kingma, N., (1991), Natural Hazard: GeomorphologicalAspect of Flood Hazard, The Netherlands: ITC. 
9. Anna, Alif N., Suharjo, \& Priyana, Y., (2015), Kajian Biofisik Lahan untuk Penilaian Kerentanan Banjir di DAS Bengawan Solo Hulu, University Research Colloquium 2015 p:9-17.

10. Mubekti \& Alhasanah, F., (2008), Mitigasi Daerah awan Tanah Longsor Menggunakan Teknik Permodelan SIG, Jurnal Teknologi Lingkungan BPPT, 9 (2): 118-126.

11. Matondang, J.P., Kahar, S., \& Sasmito, B., (2013), Analisis Zona Daerah Rentan Banjir Dengan Pemanfaatan Sistem Informasi Geografis (Studi Kasus: Kota Kendal dan Sekitarnya), Jurnal Geodesi UNDIP, 2 (2): 103-113.

12. Aji, M.D., Sudarsono, B., \& Sasmito, B., (2014), Identifikasi Zona Rawan Banjir Menggunakan Sistem Informasi Geografis (Studi Kasus: Sub DAS Dengkeng), Jurnal Geodesi UNDIP, 3(1): 36-50.

13. Peraturan Menteri Kehutanan Republik Indonesia nomor 32 Tahun 2009 tentang Tata Cara Penyusunan Rencana Teknik Hutan dan Lahan Daerah Aliran Sungai (RTkRHL-DAS).
14. Badan Penanggulangan Bencana Daerah Kabupaten Sukoharjo, (2015), Penyusunan Dokumen Risiko Bencana Kabupaten Sukoharjo 2015. Laporan Akhir, Asca Amoghasida Engineering Consultant.

15. Nugroho, S.P., \& Prayogo, T. (2008), Penerapan SIG untuk Penyusunan dan Analisis Lahan Kritis pada Satuan Wilayah Pengelolaan DAS Agam Kuantan Provinsi Sumatera Barat, Jurnal Teknologi Lingkungan BPPT, 9(2): 130-140.

16. Maryono, A., (2005), Menangani Banjir, Kekeringan, dan Lingkungan, Yogyakarta: Gadjah Mada University Press.

17. Farid, M., (2010), Banjir: Proses, Karakteristik dan Upaya Mengatasinya, Inovasi Online, Vol. 18/XXII/November 2010.

18. Balai Penelitian Tanaman Industri dan Penyegar, (2011), Potensi Bambu Sebagai Tanaman Konservasi Daerah Aliran Sungai, Retrieved July 6, 2017, Available from http://balittri.litbang.pertanian.go.id/index.ph p/berita/berita-lain/77-potensi-bambusebagai-tanaman-konservasi-daerah-aliransungai, (viewed Juni 22, 2017). 